\title{
EFFECT OF COATING CONCENTRATION AND COMBINED OSMOTIC AND HOT-AIR DEHYDRATION ON SOME PHYSICO- CHEMICAL, TEXTURAL AND SENSORY PROPERTIES OF APPLE
} SLABS

\author{
M. Taghizadeh*, M. Fathi and A.L. SajJadi \\ Department of Food Science and Technology, Ferdowsi University of Mashhad (FUM), P.O. Box: 91775-1163, \\ Mashhad. Iran
}

(Received: 11 February 2015; accepted: 26 May 2015)

In a 120 min osmotic dehydration procedure followed by an air drying process, the effect of carboxy-methyl cellulose (CMC) on some qualitative characteristics of apple slabs including browning index (BI) and rehydration capacity were studied. Moreover, the relation between textural and sensory properties, such as hardness, cohesiveness, springiness, adhesiveness and chewiness, was investigated. Samples containing higher coating concentrations (11.5\%) showed higher rehydration capacity and lower browning index compared to those with lower coating concentrations (0.25-0.5\%). Weibull distribution model was used to investigate the effect of coating concentration on drying kinetics. The results of sensory tests showed that the overall acceptance of samples is increased with decreasing coating concentration, and an appropriate correlation was found between sensory properties and textural parameters.

Keywords: coating, osmotic dehydration, air drying, texture profile analysis, sensory characteristics

Osmotic dehydration is based on the fact that the immersion of a product in a hypertonic solution with low water activity and high osmotic pressure leads to the replacement of the inner product water with the surrounding solute (JALAeE et al., 2011). During osmotic dehydration three flows occur, from which two are of more significance. The first one is the moisture flow from sample to osmotic solution and the second one is the flow of solute into sample, which occurs in the opposite direction. The third type of flow, however, is the flow of components, such as vitamins, saccharides, minerals, and flavour agents, into the solution (KHIN et al., 2005).

In this study, four different concentrations of carboxy-methyl cellulose (CMC) including $0.25 \%, 0.5 \%, 1 \%$, and $1.5 \%$ were used as coating material. The effect of CMC concentration on different physico-chemical properties of apple slab, including browning index (BI), rehydration capacity (RC), as well as some textural and sensory properties, were investigated. Furthermore, kinetic of colour change during air drying was taken into account as a function of CMC concentration.

\footnotetext{
* To whom correspondence should be addressed.

Phone: +98-38805755; fax: +98-38805755; e-mail: mtaghizadeh@um.ac.ir
} 


\section{Materials and methods}

\subsection{Raw material preparation}

Apple, cultivar Golden delicious, and sucrose (commercial) were purchased in Mashhad, Iran. The fruits were investigated for their uniformity, size, colour, and lack of damage. Initial moisture was found to be $83 \pm 0.9 \%$ (wet basis), which was determined in triplicate based on AOAC (1980) method. The apples were washed, peeled, and cut into slabs with dimensions of $7 \times 7 \times 30 \mathrm{~mm}$.

\subsection{Osmotic solutions and coatings preparation}

Sucrose solution was prepared at a concentration of $60 \%$. Additionally, calcium chloride solution (Merck, Germany) was prepared to be used as cross-linking agent. Four different CMC (Sigma) solutions at concentrations of $0.25,0.5,1$, and $1.5 \%$ were also prepared to be used for apple slabs coating.

In order to apply the coating material, samples were first immersed in the coating solution for $30 \mathrm{~s}$ and then transferred to calcium chloride solution for the same period of time. The apple slabs were then taken out of the solution and their surfaces were dried with Whitman filter papers No $42(125 \mathrm{~mm})$ for $5 \mathrm{~min}$, followed by drying process using an oven (Memmert, Schwabach, Germany) at $70^{\circ} \mathrm{C}$ for 10 min to dry out the coatings.

\subsection{Osmotic dehydration}

Each coating process lasted 120 min to assure constant weight of coated samples. Similar to coating process, all osmotic processes were carried out at room temperature at a ratio of 1:4 samples to solution (weight basis). During the first hour, samples were taken out of the solution, desiccated using filter tissues, and weighed in 15 min intervals. For the second hour of osmotic process, weighting procedure was carried out in $30 \mathrm{~min}$ intervals.

\subsection{Air drying of coated samples}

Air drying process was carried out using a convective hot air drier (Soroush Medical Company, Mashhad, Iran). Having been exposed to osmotic dehydration, samples were then transferred to an air drier at $60^{\circ} \mathrm{C}$ with air speed of $1.5 \mathrm{~m} \mathrm{~s}^{-1}$ and weighed every $30 \mathrm{~min}$. The dryer was run at least an hour prior to placing the samples into the drying chamber in order to obtain steady conditions. The drying process for each sample lasted between 6 to $7 \mathrm{~h}$ to obtain an approximate moisture content of $30 \%$.

\subsection{Colour measurement and BI determination}

Colour values were obtained with image processing techniques using Image $\mathrm{J}$ software (National Institute Health, Bethesda, MD, USA). For this purpose, samples' images were acquired using a digital camera (Canon Powershot, Model A520, Taiwan) fixed in a special imaging chamber lighted from all sides to gain the maximum resolution.

Browning index (BI), which represents the purity of brown colour, was also calculated using Eq. (1) (López-MaLo et al., 1998): 


$$
B I=\frac{100}{0.17}\left(\frac{\left(a^{*}+1.75 L^{*}\right)}{\left(5.645 L^{*}+a^{*}-3.012 b^{*}\right)}-0.31\right)
$$

where $L^{*}$ is a measure for lightness, $a^{*}$ reflects the ratio of redness to greenness, and $b^{*}$ is an indicator for the yellowness and blueness quality of the colours.

\subsection{Sensory evaluation}

A trained group of panellists consisting of 10 subjects evaluated all samples. The sensory test was performed over 3 consecutive days to prevent the panellists from becoming overly fatigued. Each session lasted $1 \mathrm{~h}$ (HARKER et al., 2002). Each panellist was presented with 4 apple slabs with different coating degrees in each single session. The panellists were then given a paper in which they were asked to score each studied parameter from 0 to 20. Giving 0 to a parameter would mean "Not at all", while giving 20 would mean "Totally". A mean of every two score that each group assigned to each of the parameters were taken as the final score.

\subsection{Rehydration capacity $(R C)$}

In order to calculate the rehydration capacity, air dried samples were transferred into a $50{ }^{\circ} \mathrm{C}$ hot water bath. After a period of $50 \mathrm{~min}$, samples were taken out and blotted using filter papers to completely remove surface water. Samples were then weighed after $5 \mathrm{~min}$ of blotting. The rehydration capacity is defined as the ratio of water gained during rehydration to water removed during drying (weight basis). It can be calculated using Eq. (2) (LewickI, 1998):

$$
\mathrm{RC}=\frac{\left(\mathrm{W}_{\mathrm{r}}-\mathrm{W}_{\mathrm{d}}\right)}{\left(\mathrm{W}-\mathrm{W}_{\mathrm{d}}\right)} \times 100
$$

where $\mathrm{W}_{\mathrm{d}}$ and $\mathrm{W}_{\mathrm{r}}$ are the weight of samples after drying and rehydration, respectively, and $\mathrm{W}$ is the initial weight of sample.

\subsection{Texture analysis (TPA)}

Texture analysis was done using a texture analyzer TA.XT2i (Brookfield) at $25^{\circ} \mathrm{C}$ with a trigger force of $5 \mathrm{~g}$. The test was carried out using a probe (TA25/1000) cylinder $(50.8 \mathrm{~mm}$ D, $20 \mathrm{~mm} \mathrm{~L}$ ).

Samples were compressed twice at a speed of $1 \mathrm{~mm} \mathrm{~s}^{-1}$ to a distance equal to $50 \%$ of the initial height. Different textural parameters, such as hardness 1, hardness 2, cohesiveness, springiness, adhesiveness, and chewiness, were evaluated.

Compression test was performed in 5 replicates and the average values were reported.

\subsection{Weibull distribution model}

In order to investigate the effect of different coating concentrations on apple slabs, a model based on the Weibull distribution was developed (BABALIs et al., 2006). This model provided the best determination coefficient $\left(\mathrm{R}^{2}\right)$ among models used for drying process, including models developed by Newton (Lewis, 1921), Henderson and PABIs (1961) and approximation of diffusion model (Yaldiz et al., 2001). During air drying of apple slabs, the effect of 
different coating concentrations on the Weibull model's parameters was investigated using Eq. (3). Calculations were carried out using Matlab software R2013a (8.1.0.604).

$$
M R=a-b \exp \left[-\left(k t^{n}\right)\right]
$$

where MR is moisture ratio, $a, b, k$, and $n$ are constants, $t$ is time (h).

The measurements were done in triplicate.

\subsection{Statistical analysis}

Analysis of variance (ANOVA) was done using SPSS software (Inc., Chicago, IL, USA Version 16.0). Significant difference at 95\% confidence interval was determined using Duncan's multiple range tests for comparison treatment means.
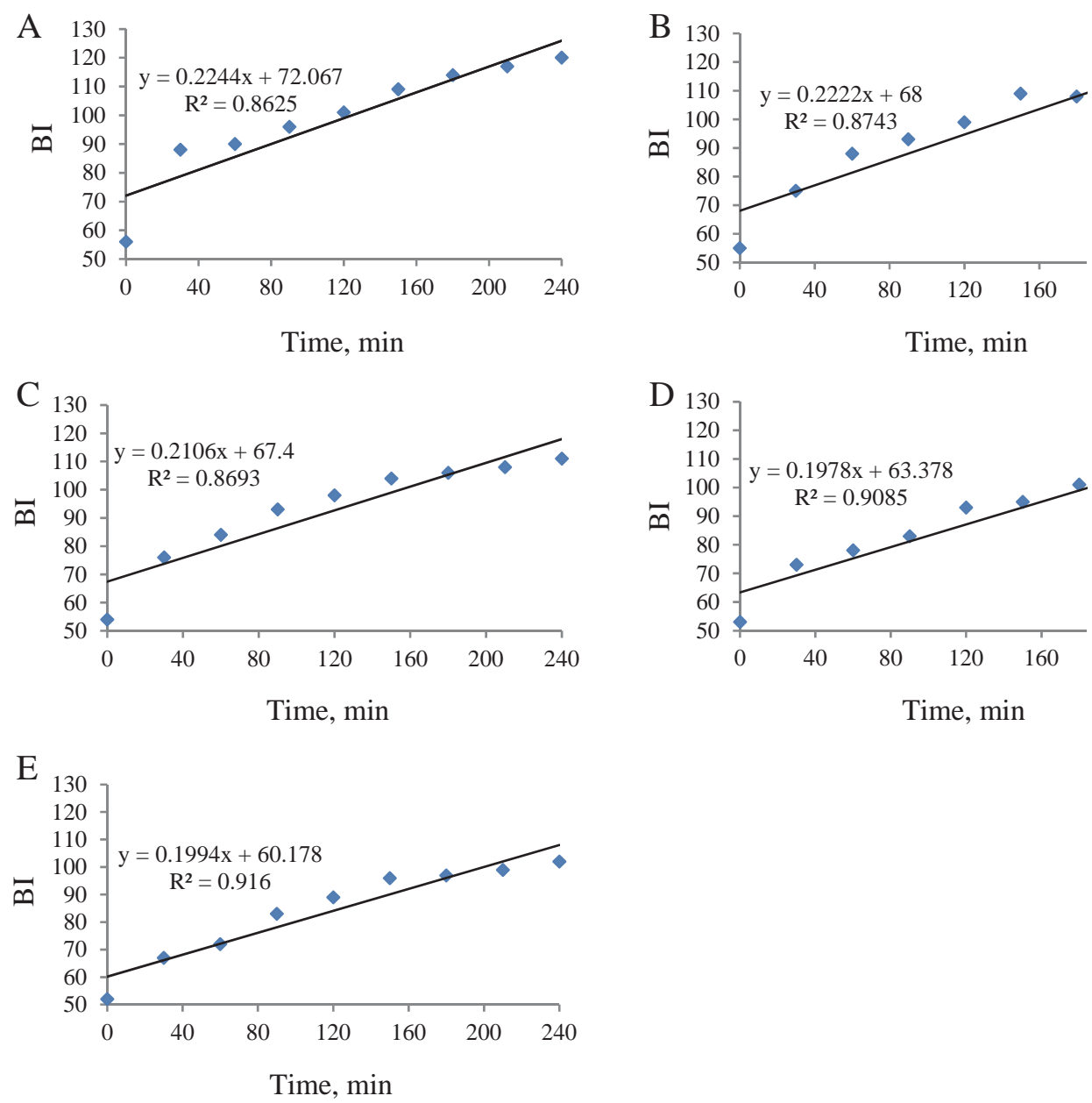

Fig. 1. The effect of carboxy-methyl cellulose (CMC) concentration on browning index (BI). (A) Control sample, (B) Sample coated with CMC 0.25\%, (C) Sample coated with CMC 0.5\%, (D) Sample coated with CMC 1\%, (E) Sample coated with CMC 1.5\% 


\section{Results and discussion}

\subsection{The effect of coating concentration on BI of dried samples during air drying}

As it can be seen in Figure 1, increasing coating concentration had a considerable effect on colour of coated samples dehydrated using both osmosis and air drying. Thus, coated apples with higher coating concentration had lower browning index. This shows that coating layer has a significant effect on colour properties of apple samples, due to its role as a barrier to oxygen, which is responsible for most browning reactions (KHIN et al., 2005). Moreover, calcium chloride, which has anti-browning properties, could reduce the browning index as well (Mazza, 1982).

Obviously, as shown in Figure 2, the samples coated with CMC 1.5\% have lower browning index than uncoated samples.
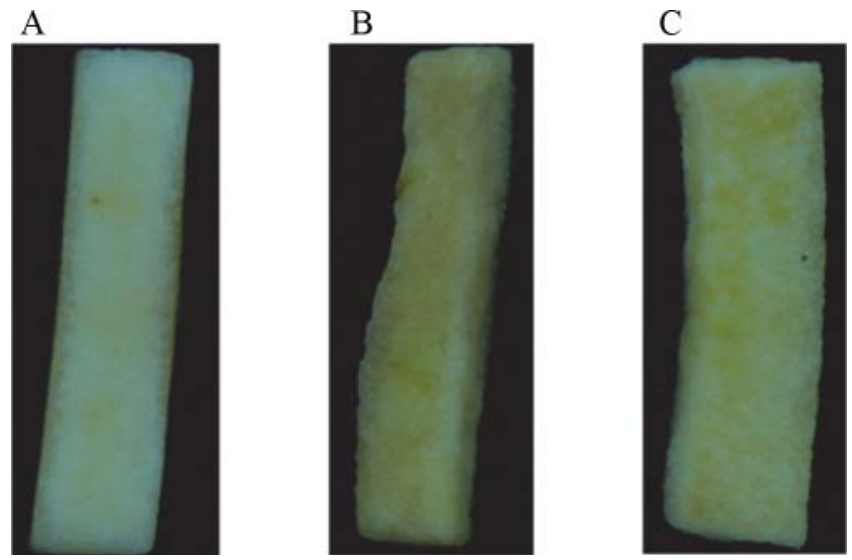

Fig. 2. The effect of coating on browning index (BI) during air drying. (A) Fresh apple, (B) Dried apple, and (C) Dried coated apple with CMC $1.5 \%$

\subsection{The effect of coating concentration on rehydration capacity}

According to Figure 3, increasing concentration of coating led to considerable effects on rehydration capacity of coated samples. Thus, coated apples with higher coating concentrations showed higher, while samples with lower concentration of coating material showed lower rehydration capacity. As it can be seen in Table 1, when applying CMC $0.25 \%$ as coating material, a slight falling rate of rehydration capacity was observed compared to uncoated sample. However, increasing coating concentration from $0.5 \%$ to $1.5 \%$ led to significant increase of rehydration capacity. The slight falling rate observed at the beginning of the curve is due to the existence of coating as a moisture barrier. The subsequent increase, though, could be due to the act of coating layer as a hindrance to heat damages, which leads to destruction of moisture vents. These vents are responsible for moisture transfer. 
Table 1 . The effect of coating concentration on rehydration capacity

\begin{tabular}{lccccc}
\hline Treatment & Initial mass (g) & $\begin{array}{c}\text { Dried sample } \\
\text { mass (g) }\end{array}$ & $\begin{array}{c}\text { After rehydration } \\
\text { mass (g) }\end{array}$ & $\begin{array}{c}\text { Moisture } \\
(\%)\end{array}$ & $\begin{array}{c}\text { Rehydration } \\
\text { capacity (\%) }\end{array}$ \\
\hline Control & $2.52 \pm 0.02$ & $0.62 \pm 0.01$ & $1.54 \pm 0.04$ & $30 \pm 0.8^{\mathrm{a}}$ & $48 \pm 1.52^{\mathrm{bc}}$ \\
CMC 0.25\% & $2.5 \pm 0.08$ & $0.64 \pm 0.02$ & $1.50 \pm 0.06$ & $31 \pm 0.7^{\mathrm{a}}$ & $46 \pm 2.8^{\mathrm{c}}$ \\
CMC 0.5\% & $2.65 \pm 0.10$ & $0.66 \pm 0.03$ & $1.65 \pm 0.13$ & $30 \pm 0.9^{\mathrm{a}}$ & $49 \pm 4.58^{\mathrm{ab}}$ \\
CMC 1\% & $2.45 \pm 0.06$ & $0.65 \pm 0.01$ & $1.84 \pm 0.09$ & $29 \pm 0.6^{\mathrm{a}}$ & $66 \pm 2.64^{\mathrm{a}}$ \\
CMC 1.5\% & $2.64 \pm 0.09$ & $0.7 \pm 0.02$ & $2.02 \pm 0.06$ & $30 \pm 0.9^{\mathrm{a}}$ & $68 \pm 1.52^{\mathrm{a}}$ \\
\hline
\end{tabular}

a, b, c. Different letters in the same row indicate significant differences at 5\%

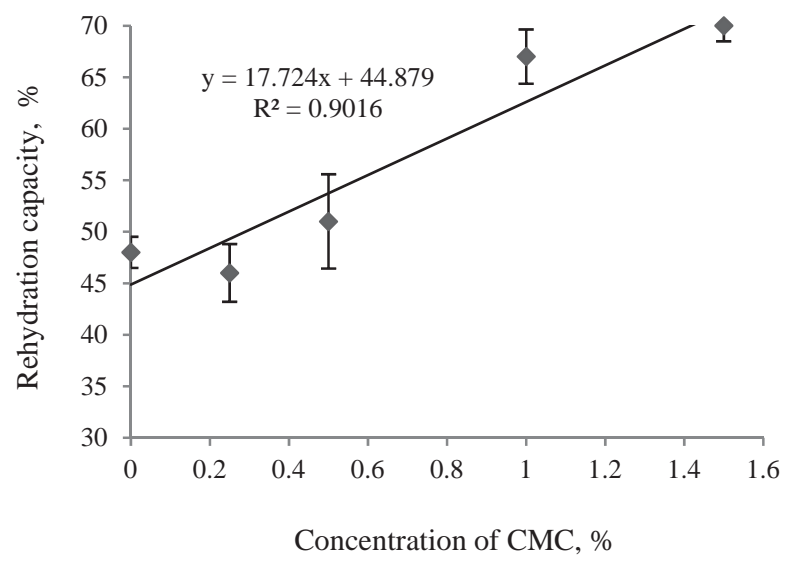

Fig. 3. The effect of coating concentration on rehydration capacity

\subsection{Mathematical modelling for drying}

Table 2 shows the effect of different coating concentrations on Weibull model parameters. Weibull model was proved to be an appropriate model for investigating the effect of different concentrations of coating on parameters related to drying. 
Table 2. The effect of different concentrations of coating on parameters of Weibull model

\begin{tabular}{lccc}
\hline Coating & $\mathrm{a}$ & $\mathrm{b}$ & $\mathrm{k}$ \\
\hline Uncoated & $0.0808 \pm 0.001^{\mathrm{e}}$ & $-0.9189 \pm 0.008^{\mathrm{a}}$ & $0.0257 \pm 0.005^{\mathrm{a}}$ \\
CMC 0.25\% & $0.1074 \pm 0.014^{\mathrm{d}}$ & $-0.8921 \pm 0.012^{\mathrm{b}}$ & $0.02362 \pm 0.007 \mathrm{~b}$ \\
CMC 0.5\% & $0.1240 \pm 0.009^{\mathrm{c}}$ & $-0.8757 \pm 0.008^{\mathrm{c}}$ & $0.02095 \pm 0.004^{\mathrm{c}}$ \\
CMC 1\% & $0.1383 \pm 0.008^{\mathrm{b}}$ & $-0.8615 \pm 0.010^{\mathrm{d}}$ & $0.0141 \pm 0.004^{\mathrm{d}}$ \\
CMC 1.5\% & $0.1612 \pm 0.018^{\mathrm{a}}$ & $-0.8414 \pm 0.009^{\mathrm{e}}$ & $0.0113 \pm 0.004^{\mathrm{e}}$ \\
\hline
\end{tabular}

\begin{tabular}{lccccc}
\hline Coating & $\mathrm{N}$ & R square & $\begin{array}{l}\text { Adjusted } \\
\text { R-square }\end{array}$ & SSE & RMSE \\
\hline Uncoated & $0.966 \pm 0.002^{\mathrm{c}}$ & 0.999 & 0.9984 & 0.0007 & 0.0118 \\
CMC 0.25\% & $0.953 \pm 0.003^{\mathrm{c}}$ & 0.9997 & 0.9996 & 0.0002 & 0.0061 \\
CMC 0.5\% & $0.966 \pm 0.006^{\mathrm{c}}$ & 0.9995 & 0.9992 & 0.0003 & 0.0084 \\
CMC 1\% & $1.072 \pm 0.008^{\mathrm{b}}$ & 0.9998 & 0.9997 & 0.0001 & 0.0050 \\
CMC 1.5\% & $1.160 \pm 0.007^{\mathrm{a}}$ & 1 & 0.9999 & 0.00000 & 0.0025 \\
\hline
\end{tabular}

a, b, c, d, e : Different letters in the same column indicate significant differences at 5\%

\subsection{The effect of coating concentration on sensory properties}

According to Table 3, samples coated with CMC $0.25 \%$ and $0.5 \%$ obtained the highest scores for overall acceptance compared to uncoated samples or those with higher levels of coating. This probably is due to the fact that during osmotic dehydration, coating acts as a barrier and prevents removal of flavouring agents. However, during air drying, high temperature led to cell collapse and high levels of coating keep the structure from further damage and lead to excessive removal of flavouring agents. In addition, panellists stated that apple taste considerably increased when coating was used. This could be due to the role of coating as a conservator of flavouring agents. Astringency, which defines as taste in the mouth after swallowing the sample, was slightly boosted along with enhancement of coating. Chewiness, as the force required removing material that adheres to the mouth (generally the palate) during the normal eating process, was increased. In the case of stickiness, due to the fact that air drying modifies the adhesive properties of surface of coated samples, no significant difference was observed between coated and uncoated samples. However, juiciness showed different levels of enhancement when coating concentration was increased. 
Table 3. The effect of coating on sensory properties of dried product

\begin{tabular}{|c|c|c|c|c|c|}
\hline Coating & Uncoated & $\begin{array}{c}\text { CMC } \\
0.25 \% \\
\end{array}$ & $\begin{array}{l}\text { CMC } \\
0.5 \%\end{array}$ & $\begin{array}{c}\text { CMC } \\
1 \% \\
\end{array}$ & $\begin{array}{l}\text { CMC } \\
1.5 \%\end{array}$ \\
\hline Hardness & $13.8 \pm 1.9^{c}$ & $13.9 \pm 1.2^{\mathrm{c}}$ & $13.3 \pm 0.8^{\mathrm{c}}$ & $15.4 \pm 0.6^{\mathrm{b}}$ & $17.3 \pm 1.1^{\mathrm{a}}$ \\
\hline Cohesiveness & $11.3 \pm 1.3^{b}$ & $13.6 \pm 1.5^{\mathrm{a}}$ & $13.9 \pm 0.9^{\mathrm{a}}$ & $14.2 \pm 1.7^{\mathrm{a}}$ & $14.6 \pm 1.3^{\mathrm{a}}$ \\
\hline Springiness & $13.5 \pm 0.7^{b}$ & $14.4 \pm 1.4^{\mathrm{a}}$ & $13.0 \pm 2.2^{b}$ & $12.0 \pm 1.3^{b}$ & $13.7 \pm 0.7^{b}$ \\
\hline Adhesiveness & $14 \pm 0.2^{b}$ & $14.9 \pm 1.6^{\mathrm{a}}$ & $15.1 \pm 0.9^{\mathrm{a}}$ & $14.9 \pm 1.2^{\mathrm{a}}$ & $15.1 \pm 1.3^{\mathrm{a}}$ \\
\hline Chewiness & $14.5 \pm 0.4^{\mathrm{a}}$ & $15.3 \pm 0.6^{\mathrm{b}}$ & $15.7 \pm 0.4^{\mathrm{b}}$ & $16.0 \pm 0.5^{\mathrm{b}}$ & $17.6 \pm 1.5^{\mathrm{a}}$ \\
\hline Apple taste & $7.5 \pm 1.5^{\mathrm{e}}$ & $11.4 \pm 1.6^{\mathrm{d}}$ & $14.7 \pm 1.3^{\mathrm{c}}$ & $17.0 \pm 0.4^{\mathrm{b}}$ & $19.6 \pm 0.4^{\mathrm{a}}$ \\
\hline Astringency & $12.5 \pm 0.5^{\mathrm{a}}$ & $13.6 \pm 0.9^{b}$ & $14.0 \pm 1.4^{\mathrm{b}}$ & $15.6 \pm 0.2^{\mathrm{b}}$ & $15.9 \pm 0.5^{\mathrm{a}}$ \\
\hline Overall acceptance & $13.6 \pm 2^{c}$ & $17.2 \pm 0.9^{\mathrm{a}}$ & $17.9 \pm 1.3^{\mathrm{a}}$ & $15.5 \pm 2^{b}$ & $14.6 \pm 1.9^{\mathrm{b}}$ \\
\hline
\end{tabular}

a, b, c, d, e : Different letters in the same row indicate significant differences at 5\%

\subsection{The effect of coating on textural properties of dehydrated product}

According to Table 4, osmotic dehydration improved hardness of apple slabs in both coated and uncoated samples. However, this enhancing effect is more significant in case of coated samples. It happens due to the fact that during osmosis, water displaces simultaneously with solid substances. Along with this displacement, calcium chloride releases calcium ions, which diffuse into apple tissue causing to produce calcium pectate. The whole process increases hardness of fruit (BALDwIN et al., 1995). It seems that CMC can remarkably enhance texture cohesiveness as well as its hardness. Chewiness, which is a factor derived from hardness, cohesiveness, and springiness, is also increased.

Samples that were both osmotic and air dehydrated showed lowest elasticity. This could be due to excessive absorption of sucrose leading to higher fragility and decreasing texture springiness (Wong et al., 1994). In the case of adhesiveness, no considerable difference was found between the studied samples. This might be as a result of air drying, which modifies surface adhesiveness.

Table 4. The effect of coating on textural properties of dried product

\begin{tabular}{lcccccc}
\hline & Hardness 1 & Hardness 2 & Cohesiveness & Springiness & Adhesiveness & Chewiness \\
\hline Air dried & $210 \pm 26^{\mathrm{c}}$ & $191 \pm 22^{\mathrm{c}}$ & $0.6 \pm 0.021^{\mathrm{a}}$ & $1.44 \pm 0.005^{\mathrm{a}}$ & $0.47 \pm 0.023^{\mathrm{a}}$ & $181.4 \pm 23^{\mathrm{c}}$ \\
Osmosed-air dried & $289 \pm 28^{\mathrm{b}}$ & $240 \pm 15^{\mathrm{b}}$ & $0.62 \pm 0.024^{\mathrm{ab}}$ & $1.41 \pm 0.004^{\mathrm{b}}$ & $0.49 \pm 0.020^{\mathrm{a}}$ & $260.6 \pm 29^{\mathrm{b}}$ \\
$\begin{array}{l}\text { Osmosed-air } \\
\text { dried-coated with }\end{array}$ & $445.8 \pm 21^{\mathrm{a}}$ & $398 \pm 25^{\mathrm{a}}$ & $0.67 \pm 0.040^{\mathrm{a}}$ & $1.43 \pm 0.010^{\mathrm{a}}$ & $0.48 \pm 0.027^{\mathrm{a}}$ & $426 \pm 28^{\mathrm{a}}$ \\
CMC 1.5\% & & & & & & \\
\hline
\end{tabular}

a, b, c. Different letters in the same column indicate significant differences at 5\%

\subsection{Correlation between textural and sensory properties}

According to Table 5, textural properties were generally well correlated with sensory parameters. The highest rate of correlation belonged to hardness. This is in agreement with previous works reported (MonTEJANo et al., 1985; MuÑoz, 1986). Instrumental cohesiveness showed lowest correlation with its sensorial equivalent. This is in agreement with a similar 
work reported by Lyon and co-workers (1980). Other parameters showed appropriate correlation with greater than 0.82 .

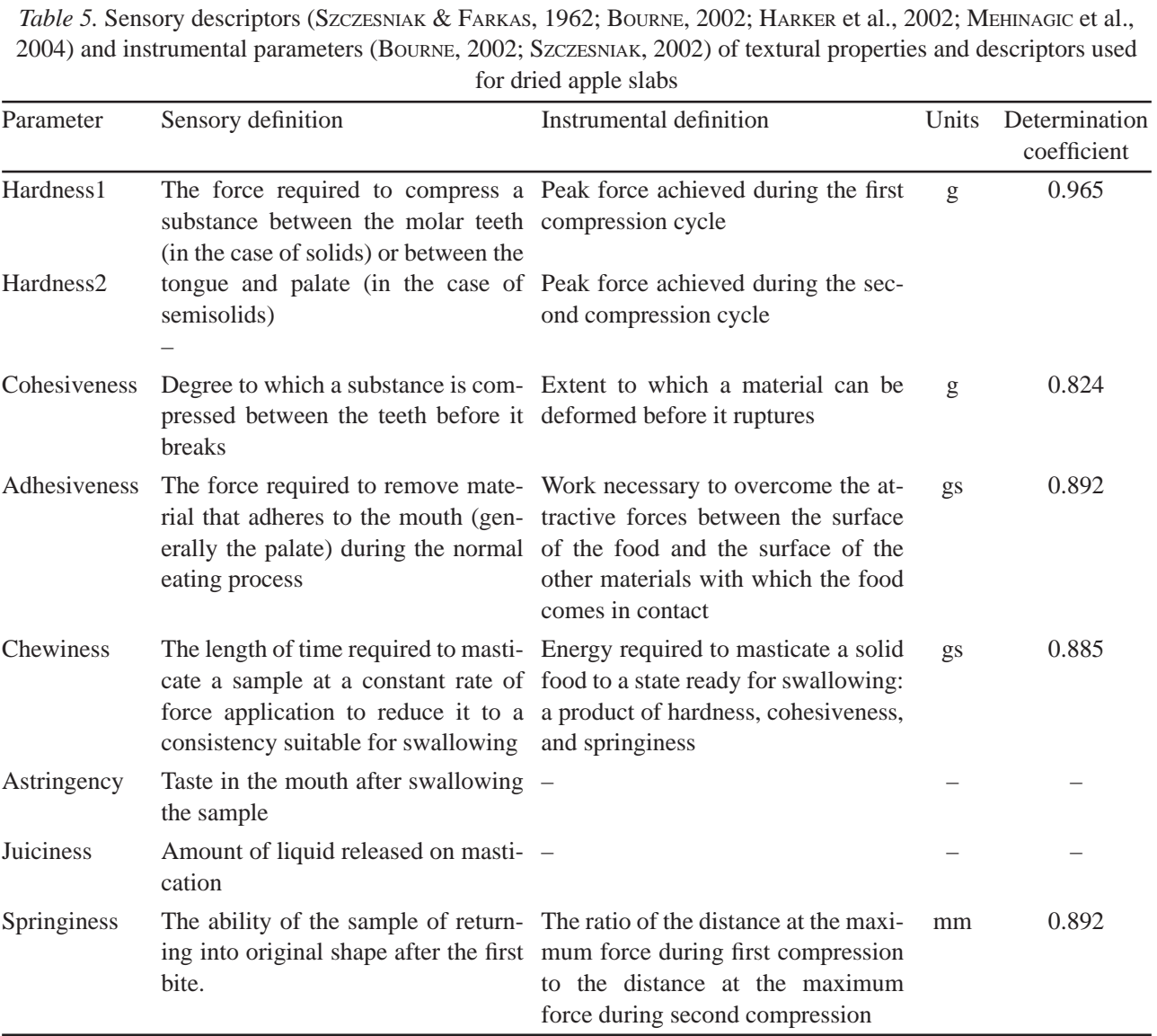

\section{Conclusions}

The effect of coating concentration on browning index and textural properties of apple slabs was investigated. It was found that CMC coating can effectively prevent the product from browning reaction. This was best achieved when a CMC concentration of $1.5 \%$ was used. Although coating solely had considerable effect on enhancement of textural properties such as hardness and cohesiveness, this enhancement was best evident when coating process was followed by an osmotic dehydration. Apples coated with less coating concentrations showed lower rehydration capacity, while samples with more concentration of coating generally had higher rehydration capacity. Statistical parameters showed that Weibull distribution model had high potential in modelling of air drying process (all were above 0.999). Sensory parameters showed appropriate correlation with TPA parameters. Coating had positive effect on some sensory parameters, such as astringency, apple taste, and overall acceptance. 


\section{References}

AOAC (1980): Offcial methods of analysis, $13^{\text {th }}$ ed. Association of Offcial Analytical Chemists, Washington, DC. Method No. 22.013.

Babalis, S.J., Papanicolaou, E., Kyriakis, N. \& Belessiotis, V.G. (2006): Evaluation of thin-layer drying models for describing drying kinetics of figs (Ficus carica). J. Food. Eng., 75, 205-214.

Baldwin, E., Nisperos-Carriedo, M. \& BaKer, R. (1995): Edible coatings for lightly processed fruits and vegetables. HortScience, 30, 35-38.

Bourne, M. (2002): Food texture and viscosity: concept and measurement. Academic Press, London, San Diego. 427 pages.

Harker, F., Maindonald, J., Murray, S., Gunson, F., Hallett, I. \& Walker, S. (2002): Sensory interpretation of instrumental measurements 1: Texture of apple fruit. Postharvest Biol. Tec., 24, 225-239.

Henderson, S.M. \& Pabis, S. (1961): Grain drying theory I. Temperature effect on drying coefficient. J. Agr. Eng. Res., 63, 169-174.

Jalaee, F., Fazeli, A., Fatemian, H. \& Tavakolipour, H. (2011): Mass transfer coefficient and the characteristics of coated apples in osmotic dehydrating. Food Bioprod. Process, 89, 367-374.

Khin, M.M., Zhou, W. \& Perera, C. (2005): Development in the combined treatment of coating and osmotic dehydration of food - A review. Int. J. Food Eng., 1, 36-84.

LEWICKI, P.P. (1998): Some remarks on rehydration of dried foods. J. Food Eng., 36, 81-87.

LEWIS, W.K. (1921): The rate of drying of solid materials. Ind. Eng. Chem., 13, 427-432.

López-Malo, A., Palou, E., Barbosa-Canovas, G., Welti-Chanes, J. \& Swanson, B. (1998): Polyphenoloxidase activity and color changes during storage of high hydrostatic pressure treated avocado puree. Food Res. Int., 31, 549-556

Lyon, C., Lyon, B., Davis, C. \& Townsend, W. (1980): Texture profile analysis of patties made from mixed and flake-cut mechanically deboned poultry meat. Poultry Sci, 59, 69-76.

Mazza, G. (1982): Moisture sorption isotherms of potato slices. Int. J. Food Sci. Tech., 17, 47-54.

Mehinagic, E., Royer, G., Symoneaux, R., Bertrand, D. \& Jourjon, F. (2004): Prediction of the sensory quality of apples by physical measurements. Postharvest Biol. Tec., 34, 257-269.

Montejano, J., Hamann, D. \& Lanier, T. (1985): Comparision of two instrumental methods with sensory texture of protein gels 2. J. Texture Stud., 16, 403-424.

Muñoz, A.M. (1986): Development and application of texture reference scales. J. Sens. Stud., 1, 55-83.

Szczesniak, A.S. \& Farkas, E. (1962): Objective characterization of the mouthfeel of gum solutions. J. Food Sci., 27, 381-385.

SzCZESNIAK, A.S. (2002): Texture is a sensory property. Food Qual. Prefer., 13, 215-225.

Wong, D.W., Tillin, S.J., Hudson, J.S. \& Pavlath, A.E. (1994): Gas exchange in cut apples with bilayer coatings. J. Agr. Food Chem., 42, 2278-2285.

Yaldiz, O., ErTEKin, C. \& Uzun, H.I. (2001): Mathematical modeling of thin layer solar drying of sultana grapes. Energy, 26, 457-465. 